COMMON THINGS 
FORDHAM UNIVERSITY PRESS NEW YORK 2014

COMMONALITIES

Timothy C. Campbell, series editor 


\section{COMMON THINGS}

Romance and the Aesthetics of Belonging in Atlantic Modernity

JAMES D. LILLEY 
All rights reserved. No part of this publication may be reproduced, stored in a retrieval system, or transmitted in any form or by any means-electronic, mechanical, photocopy, recording, or any otherexcept for brief quotations in printed reviews, without the prior permission of the publisher.

"Henry Mackenzie's Ruined Feelings: Romance, Race, and the Afterlife of Sentimental Exchange." Copyright (C) 2007 New Literary History, The University of Virginia. This article first appeared in New Literary History Volume 38, Issue 4, Autumn, 2007, pages 649-66.

"Studies in Uniquity: Horace Walpole's Singular Collection" reprinted from ELH, vol. 80.1 (2013). Copyright (c) The Johns Hopkins University Press.

Fordham University Press has no responsibility for the persistence or accuracy of URLs for external or third-party Internet websites referred to in this publication and does not guarantee that any content on such websites is, or will remain, accurate or appropriate.

Fordham University Press also publishes its books in a variety of electronic formats. Some content that appears in print may not be available in electronic books.

Library of Congress Cataloging-in-Publication Data

Lilley, James D. (James David), 1971-

Common Things : Romance and the Aesthetics of Belonging in Atlantic Modernity / James D. Lilley. pages $\mathrm{cm}$. - (Commonalities)

Includes bibliographical references and index.

ISBN 978-0-8232-5515-3 (cloth : alk. paper)

1. Literature-Philosophy-History. I. Title.

$\mathrm{PN}_{45}$.L467

$801-\mathrm{dc} 23$

2013009214

Printed in the United States of America

$161514 \quad 54321$

First edition

THE

A M E R I C A N

LITERATURES

I N I T I A T I V E
A book in the American Literatures Initiative (ALI), a collaborative publishing project of NYU Press, Fordham University Press, Rutgers University Press, Temple University Press, and the University of Virginia Press. The Initiative is supported by The Andrew W. Mellon Foundation. For more information, please visit www.americanliteratures.org. 